\title{
APLICAÇÃO DO MÉTODO DA ELETRORRESISTIVIDADE NA INVESTIGAÇÃO E MAPEAMENTO DA CONTAMINAÇÃO POR CEMITÉRIOS - $O$ EXEMPLO DO CEMITÉRIO DE VILA REZENDE, PIRACICABA/SP
}

\author{
Robson Willians da Costa Silva \\ Orientador: Dr. Walter Malagutti Filho (DGA-UNESP/Rio Claro) \\ 156 p. - Dissertação (Mestrado) - Defesa 10.04 .2008
}

\begin{abstract}
RESUMO. Este trabalho investigou e mapeou a contaminação por necrochorume da água subterrânea no aqǘfero freático do cemitério de Vila Rezende, situado na zona norte do município de Piracicaba - São Paulo, Brasil. Para tanto, foi aplicado o método da eletrorresistividade, por meio das técnicas de sondagem elétrica vertical (SEV) e imageameanto elétrico (2D), arranjos schlumberger e dipolo-dipolo respectivamente, sendo a primeira com objetivo de estudar a distribuição do parâmetro resistividade elétrica verticalmente (1D) e a outra verticalmente e horizontalmente (2D e 3D). Os resultados da SEV indicam uma profundidade do nível freático entre 3,1 e 5,1 m na época de estiagem, com dois sentidos de fluxo subterrâneo, sendo um sentido a SW e o outro a SE. A subsuperfície do cemitério apresenta uma camada pouco espessa de aterro com sedimentos de textura arenosa, predominando logo abaixo sedimentos argilosos da Formação Corumbataí e diabásio das Intrusivas Básicas respectivamente. 0 cemitério apresenta condições físico-químicas dos materiais em subsuperfície desfavoráveis para percolação do necrochorume, mas facilita o fenômeno de saponificação dos cadáveres. Os resultados obtidos das linhas de imageamento elétrico (2D) indicam duas prováveis plumas de contaminante em zona não-saturada, uma na direção SW e outra a SE, ambas seguindo a direção do fluxo subterrâneo. Mas em zona saturada predomina uma pluma a SE sob as quadras $Q-08,04$ e 01, e também fora dos limites do cemitério. As áreas com baixa resistividade (anomalia condutiva), apresentadas nas seções geoelétricas e nos mapas de resistividade elétrica, demonstram que a contaminação tem ligação com a profundidade do nível freático e com o tempo de sepultamento. Por meio dos resultados obtidos, como localização e expansão das prováveis plumas, foram locados seis poços de monitoramento. Os métodos aplicados neste trabalho demonstraram como um instrumento indireto importante para avaliação da qualidade ambiental em cemitérios.
\end{abstract}

ABSTRACT. This work investigated and mapped the contamination for necrochorume of the groundwater in the freatic aquifer of Vila Rezende's cemetery, located in the north area from Piracicaba - São Paulo, Brazil. For that, electrical resistivity method was applied using vertical electric sounding (VES) and 2D electrical imaging techniques, schlumberger and dipole-dipole arrays respectively, being the first with the objective to investigate the electric resistivity vertically (1D) and the other vertically and horizontally (2D and 3D). The results of VES indicate a depth of water table among 3,1 and 5,1 $\mathrm{m}$ in drought, with two flow directions, being a the SW and another the SE. Cemetery underground presents a fine layer of embankment with sediments of sandy texture, prevailing soon lowers clayey sediments of the Corumbataí Formation and diabase of the Basic Intrusive respectively. The cemetery presents physical-chemistry geological conditions unfavorable for percolation of the necrochorume, but facilitates the phenomenon of human corpse saponification. The obtained results of the lines of electrical imaging (2D) indicate two probable contamination plume in unsaturated zone, a in SW and another to SE direction, both following the groundwater flow. But in saturated zone prevails a plume at SE under the blocks $Q-08,04$ and 01 , and also out of the cemetery of the limits. The areas with low resistivity (conductive anomaly), presented in the geoelectrical sections and in the electrical resistivity maps, demonstrate that the contamination has connection with the depth of the water table and time of burial. Through the obtained results, as location and expansion of the probable plumes, were suggested six monitoring wells. The applied methods in this work demonstrated as an important indirect instrument for evaluation of the environmental quality in cemeteries. 